\title{
Burnout assessment in nurses from a general emergency service
}

\author{
Avaliação do burnout em enfermeiros de um serviço de urgência geral \\ Evaluación del burnout en enfermeros de un servicio de urgencia general
}

\section{Daniela Filipa Rocha Nobre' \\ ORCID: 0000-0003-0507-8694}

Isabel Cristina Mascarenhas Rabiais" ORCID: 0000-0002-8342-1171

Patrícia Cruz Pontífice Sousa Valente Ribeiro" ORCID: 0000-0003-0749-9011

Paulo Rosário Carvalho Seabra"'I ORCID: 0000-0001-8296-1021

'Clínica de Hemodiálise Eudorial. Óbidos, Portugal. "Universidade Católica Portuguesa, Escola de Enfermagem de Lisboa. Lisboa, Portugal.

II'Escola Superior de Enfermagem de Lisboa. Lisboa, Portugal.

How to cite this article:

Nobre DFR, Rabiais ICM, Ribeiro PCPSV, Seabra PRC. Burnout assessment in nurses from a general emergency service. Rev Bras Enferm. 2019;72(6):1457-63. doi: http://dx.doi.org/10.1590/0034-7167-2017-0870

Corresponding Author: Paulo Rosário Carvalho Seabra E-mail: pauloseabra@esel.pt

Submission: 11-17-2017

Approval: 02-28-2019

\begin{abstract}
Objective: To assess the level of Burnout among nurses in a general emergency department. Method: Quantitative, descriptive, correlational and cross-sectional study. 32 nurses from a general adult emergency department answered a questionnaire to evaluate Burnout. (Copenhagen Burnout Inventory). Result: It was verified that $59.4 \%$ of the nurses presented total Burnout. Work-related burnout was the subscale with the highest average score. It was found that the lower the age and the longer the time working in the institution, the higher the level of Burnout. Longer professional experience was related to lower levels of Burnout. There were also higher scores of Burnout among participants who thought about changing their profession, their institution or their service. Conclusion: The prevalence of Burnout is high. Professional Burnout was the most critical subscale. Age and the current work are the subscales that most influence perceived Burnout

Descriptors: Professional Burnout; Psychological Stress; Nursing; Emergencies; Working Conditions.
\end{abstract}

\section{RESUMO}

Objetivo: Avaliar o nível de Burnout dos enfermeiros de um serviço de urgência geral. Método: Estudo quantitativo, descritivo, correlacional e transversal. Participaram 32 enfermeiros de um serviço de urgência geral de adultos que responderam a um questionário para avaliar o Burnout. (Copenhagen Burnout Inventory). Resultados: Verificou-se que 59,4\% dos enfermeiros estavam em Burnout Total, sendo o Burnout relacionado com o trabalho, a dimensão com valor mais elevado. Apurou-se que quanto menor a idade, quanto mais tempo na instituição, maior o nível de Burnout. Quanto mais tempo de exercício profissional, menor o Burnout. Verificou-se ainda valores mais elevados de Burnout nos participantes que pensam em mudar de profissão, nos que pensam em mudar de instituição e mudar de serviço. Conclusão: $A$ prevalência de Burnout é elevada. O Burnout profissional é a dimensão mais prejudicada. A idade e o contexto de exercício são as dimensões que mais influenciam a perceção de Burnout. Descritores: Esgotamento Profissional; Enfermagem; Estresse Psicológico; Emergências; Condições de Trabalho.

\section{RESUMEN}

Objetivo: Evaluar el nivel de Burnout de los enfermeros de un servicio de urgencia general. Método: Estudio cuantitativo, descriptivo, correlacional y transversal. Participaron 32 enfermeros de un servicio de urgencia general de adultos que respondieron a un cuestionario para evaluar el Burnout. (Copenhague Burnout Inventory). Resultados: Se verificó que el $59,4 \%$ de los enfermeros estaban en Burnout Total, siendo el Burnout relacionado con el trabajo, la dimensión con valor más elevado. Se ha comprobado que cuanto menor es la edad, cuanto más tiempo en la institución, mayor es el nivel de Burnout. Cuanto más tiempo de ejercicio profesional, menor el Burnout. Se verificaron aún valores más elevados de Burnout en los participantes que piensan en cambiar de profesión, en los que piensan en cambiar de institución y cambiar de servicio. Conclusión: La prevalencia de Burnout es elevada. El Burnout profesional es la dimensión más perjudicial. La edad y el contexto de ejercicio son las dimensiones que más influyen la percepción de Burnout.

Descriptores: Agotamiento Profesional; Enfermería; Estrés Psicológico; Emergencias; Condiciones de Trabajo. 


\section{INTRODUCTION}

Work is one of the ways of meetings diverse human needs, such as self-realization, maintenance of interpersonal relationships and survival. At the same time, it may represent a threat when it poses health risks and the workers do not have enough resources to protect themselves. These uncontrolled risk factors can be associated with the Burnout syndrome ${ }^{(1)}$.

There is no single definition of the Burnout syndrome, however, the most widely accepted one describes it as a state of physical, emotional, and mental exhaustion caused by long-term involvement in situations that are emotionally demanding in the workplace ${ }^{(2)}$. While stress, a related concept, is a phenomenon of temporary adaptation to an external or internal stimulus, Burnout results from a failure of adaptation to prolonged and recurrent exposure to job stress. It is a chronic dysfunction ${ }^{(3)}$ that generally affects professionals who are in direct contact with people, and it is common among health professionals ${ }^{(4)}$.

Maslach et al. ${ }^{(5)}$ consider that Burnout is a multidimensional syndrome composed of three subscales: emotional exhaustion, depersonalization, and reduced personal accomplishment. Emotional exhaustion is characterized by lack of energy and enthusiasm and a feeling of depletion of emotional resources. This can be accompanied by feelings of frustration and tension among workers, since they realize that they are no longer able to spend the same amount of energy on the care of their clients or other people as they did before. Depersonalization is characterized by an emotional insensitivity, which makes the professional interact with clients, colleagues and with the organization in a dehumanized manner. Reduced personal accomplishment is characterized by a negative self-assessment of workers, who become unhappy and unsatisfied with their professional development, and present a consequent decline in feelings of competence and success, as well as in their ability to interact with others ${ }^{(6)}$. Several authors have described the process, the manifestations and the sequence of the different subscales of Burnout, giving consistency to the concept, opening possibilities for its measurement and proposing evolutions of the original subscales ${ }^{(2-4)}$. The Copenhagen Burnout Inventory is one of the latest measurement tools for Burnout and consists of three scales: Personal Burnout, Work-related Burnout, and Client-related Burnout ${ }^{(4)}$.

\section{Burnout among nurses}

In studies with different professions, the Burnout syndrome is highlighted as predominant among nurses. Burnout affects nurses all over the world in a variety of work contexts. It brings negative consequences for workers and their clients, and feelings of frustration, coldness and indifference stand out ${ }^{(7)}$.

According to França \& De Martino ${ }^{(1)}$, in the experience of health professionals, the lack of adaptation to the needs arising from the mental structure and ergonomic contents of tasks translates into dissatisfaction, distress or an anxiety condition, rarely expressed in words or explained by workers themselves. On the other hand, Martins \& Valente ${ }^{(8)}$ affirm that the intense workload, the provision of care, the nurse-client relationship and other responsibilities are important stressors in terms of physical and mental exhaustion.
These factors generate high levels of tension, distress and anxiety which lead to absenteeism, neglected tasks, job switch, health problems, and even work leaves.

The nursing care itself and the organizational characteristics related to rampant capitalism, competitiveness and search for quality and productivity reinforce the mechanisms of stress development ${ }^{(9-10)}$. Batista et al. ${ }^{(11)}$ believe that stress, which is a precursor of Burnout, is a multi-causal process with individual, social and organizational repercussions. In addition, this study demonstrated the need to detect early variables associated with nursing team work.

Faced with the impact of stress and Burnout, three levels of effective preventive interventions can be emphasized: organizational strategies, which are applied to the work environment; individual strategies, focused on personal responses and emotional self-regulation during stressful situations; and combined strategies, which focus on the interaction between the occupational and individual contexts ${ }^{(6,12)}$.

\section{Burnout among nurses of a general emergency department}

Nursing professionals who work in emergency services are the most susceptible to this syndrome. The mission of these professionals is to help clients with acute conditions, trauma, life-saving situations, among others, so they have to manage suffering, disablement and even death ${ }^{(13)}$. The job places heavy demands on the professional, as it requires attention, concentration and strength, both in physical and emotional dimensions. Therefore, nurses must be aware that they need to protect themselves in order to carry out their professional activities without damaging their own health ${ }^{(8,14)}$. The stressful elements in nursing work are related to excessive mental work, such as the pressure experienced in unpredictable situations that require rapid decision-making and the excessive workload ${ }^{(14)}$. Filgueira et al. ${ }^{(15)}$ believe that scenes of constant violence and the provision of direct care for critically ill clients are determinants of professional burnout, which can lead to psychic and physical illness. This problem must be considered collective and institutional, and not only an individual problem ${ }^{(16)}$. Therefore, it is important to find effective coping strategies.

\section{Coping strategies}

To deal with the problems that arise in the work and in the institution, nurses need to manage the different functions they perform within the same service, pondering, delegating and establishing priorities to solve different situations ${ }^{(17)}$. According to Silva et al. ${ }^{(18)}$ there are possible strategies to reduce burnout among nurses: discussion about workload and number of working hours; better wages; psychological follow-up for workers who deal with pain, suffering and death; promotion of emotional support among co-workers; and analysis of mental health conditions related to stress at work in the periodic examinations. These strategies will be viable when Burnout stops being regarded as an individual responsibility or a problem related only to the professional-user relationship, and starts being recognized as a problem of the individual-work-process-organization relationship ${ }^{(6)}$. 
In addition to the critical ability to prioritize responses and give specific nursing diagnoses for complaints (signs and symptoms of clients and family members), nurses must have technical and scientific knowledge to establish an individualized care plan, taking into account the set of norms and functioning dynamics instituted to organize the work process in emergency services ${ }^{(19)}$.

The starting point to investigate more about this issue came from experiences with several nursing teams, when fatigue could be observed, but with no neglect of duties related to care and to the relationship with the client and significant people and maintaining the relationship with the multidisciplinary teams. Therefore, we questioned the reality of the nurses of the emergency service.

\section{OBJECTIVE}

To assess the level of Burnout among nurses in a general emergency department.

\section{METHOD}

\section{Ethical aspects}

An authorization request for this study was sent to the Research Ethics Committee of the Hospital. Participants were informed of the objectives of the study and signed the informed consent form. To respect ethical principles, the use of the Copenhagen Burnout Inventory ( $\mathrm{CBI}$ ) was authorized by the author of the version adapted and validated for Portugal ${ }^{(4)}$.

\section{Design, setting and period}

This is a quantitative, descriptive, correlational and cross-sectional study. The data was collected between April and June 2015.

\section{Data collection, sample and inclusion criteria}

The data were collected through a questionnaire that was left in the emergency department under the responsibility of the Responsible Nurse, who distributed the questionnaires and collected them in an enclosed envelope to be delivered to the main researcher.

The study sample consisted of thirty-two nurses of an adult general emergency service in the region of Lisbon $(71.1 \%$ of a total population of 45). The convenience sample with voluntary participation tried to obtain the maximum number of participants. The only inclusion criteria were being a nurse and working in the emergency department.

\section{Study protocol}

The socio-professional characteristics of the participants were identified and the Copenhagen Burnout Inventory (CBI) was used ${ }^{(4)}$. This is an instrument with nineteen items, distributed on three scales: the personal Burnout scale has six items that evaluate the degree of physical and psychological exhaustion experienced by the person; the work-related Burnout scale with seven items examines the degree of physical and psychological fatigue and the perceived exhaustion of the person in relation to their work; the client-related Burnout scale with six items assesses the degree of physical and psychological fatigue and perceived exhaustion in relation to the work performed with the clients. The frequency of each feeling is evaluated on a Likert scale with five options (1-5), in which 1 corresponds to zero (0\%) and 5 corresponds to $100 \%$. The remaining responses correspond to $25 \%, 50 \%$ and $75 \%$. In this instrument and in each of its subscales, higher scores correspond to a higher perceived Burnout. A score equal to or greater than $50 \%$ in the total scale and in the subscales is considered as a high level of Burnout. In the present study, the scale demonstrated good reliability, with a Cronbach's alpha of 0.954 .

\section{Data analysis}

The Statistical Package for the Social Sciences (SPSS ${ }^{\circledR}$ ) version 22 was used for the statistical calculations. Descriptive statistics were performed with measures of central tendency and dispersion. The normality distribution of the data in each variable was determined. Parametric tests were used when the distribution was normal (Kolmogorov Smirnov> 0.05) (Student's t-test, Pearson's correlation test). Non-parametric tests were used when at least one of the variables had a non-normal distribution. The level of statistical significance was set at $p<0.05$.

\section{RESULTS}

\section{Socio-professional characteristics of nurses}

Of the total number of participants $(n=32), 17$ (53.1\%) were male. The median age was 30.0 years [interquartile range 4 ]. $\mathrm{Re}-$ garding the level of education, 29 (90.6\%) had an undergraduate "licentiate" degree and 3 (9.4\%) had a master's degree. There was no reference to bachelor or doctorate degrees. Regarding the professional category, it was verified that $3(9.4 \%)$ were specialist nurses and 29 (91.6\%) were general care nurses. The time in the profession ranged from 1 (minimum) to 25 (maximum) years, and 14 professionals (43.7\%) were in the predominant range of 6 to 10 years. The time working in the hospital studied varied between 0 ( $\min )$ and $3(\max )$ years, and the 3-year time predominated in 21 participants (65.6\%). On the other hand, the time working in the emergency service varied between 0 ( $\mathrm{min}$. ) and 6 (max.) years, and the 3-year time predominated in 19 participants (59.4\%).

Eight participants (25\%) affirmed they also worked in another institution, while 24 (75\%) only worked in the institution studied.

Regarding the type of schedule of the nurses, 31 (96.9\%) work rotating shifts and 1 (3.1\%) has a fixed work schedule. As for the number of working hours, 2 nurses (6.25\%) work 20 hours a week, 12 (37.5\%) 40 hours a week and 18 (56.25\%) work more than 60 hours a week.

Regarding the type of employment contract, it was verified that: 17 nurses $(53.1 \%)$ have permanent employment contracts (are linked to the public service until retirement age); 10 (31.25\%) have individual temporary employment contracts (are linked to the public service as long as the activity is necessary, with no need to renew); 3 (9.4\%) have service provision contracts (paid 
according to the days worked); and 2 (6.25\%) have a fixed-term contract (lasting for an established period of time).

Regarding the last vacation taken: 9 nurses (28.1\%) reported that it was one month before the interview; 6 (18.8\%) took a vacation two months before; 1 (3.1\%) three months before; 3 (9.4\%) four months before; 2 (6.3\%) five months before; 5 (15.6\%) six months before; 3 (9.4\%) seven months before; 1 (3.1\%) eight months before; and 2 (6.3\%) nine months before.

When asked if they thought about changing profession in the last month, 17 nurses (53.1\%) answered yes, while 15 (46.9\%) answered that they did not; when asked about their desire to change institutions, 14 (43.8\%) answered yes and 18 (56.3\%) answered no; and when questioned about desire to change service, 15 (47.9\%) showed willingness to do so, while 17 (53.2\%) wished to stay in the same service.

\section{Burnout perception among nurses}

Regarding the levels of Burnout, the following results were obtained in each subscale: in the Personal Burnout scale the mean value was $51.4 \%$; in the Workrelated Burnout scale the mean score was $58.5 \%$; in the Client-related Burnout scale the mean score was $53.1 \%$. In all 3 subscales a high level of Burnout was found. Regarding total burnout, the mean score was $54.33 \%$, which corresponds to Total burnout. Regarding the number of nurses with total burnout, $78.1 \%$ $(n=25)$ of nurses presented total burnout, while $21.9 \%$ $(\mathrm{n}=7)$ did not (Table 1).

All of these items are significantly related to the Burnout syndrome. The work-related Burnout is the subscale that most contributes to Total burnout $\left(r_{p}=.946\right.$; $\mathrm{p}<0.001$ ), as shown in the correlation table (Table 2 ).

Table 1 - Number of nurses with a high level of total burnout and in the subscales personal burnout, work-related burnout, and client-related burnout, Lisbon, Portugal, 2017

\begin{tabular}{llrc}
\hline & & $\mathbf{n}$ & $\%$ \\
\hline Personal Burnout & Low level of Burnout & 13 & 40.6 \\
& High level of Burnout & 19 & 59.4 \\
Work-related Burnout & Low level of Burnout & 10 & 31.3 \\
& High level of Burnout & 22 & 68.7 \\
Client-related Burnout & Low level of Burnout & 10 & 31.2 \\
& High level of Burnout & 18 & 56.3 \\
Total Burnout & Low level of Burnout & 7 & 21.9 \\
& High level of Burnout & 25 & 78.1 \\
\hline
\end{tabular}

Table 2 - Correlation between the subscales personal burnout, work-related burnout and client-related burnout with the total Copenhagen Burnout Inventory (CBI) scale, Lisbon, Portugal, 2017

\begin{tabular}{ccccc}
\hline & $\begin{array}{c}\text { Total } \\
\text { Burnout }\end{array}$ & $\begin{array}{c}\text { Personal } \\
\text { Burnout }\end{array}$ & $\begin{array}{c}\text { Work- } \\
\text { related } \\
\text { Burnout }\end{array}$ & $\begin{array}{c}\text { Client- } \\
\text { related } \\
\text { Burnout }\end{array}$ \\
\hline \multirow{2}{*}{$\begin{array}{c}\text { Pearson's Correlation } \\
\text { Total Burnout }\end{array}$} & 1 & $.943^{* *}$ & $.946^{* *}$ & $.925^{* *}$ \\
$\mathrm{n}$ & 32 & 32 & 32 & 32 \\
\hline
\end{tabular}

Note: ${ }^{* *}$ Correlation is significant at the 0.01 level; $r_{p}=$ Pearson's Correlation Test.

\section{Burnout perception in association to the socio-professional characteristics of nurses}

Regarding Burnout levels and their association to social, demographic and occupational variables, no statistically significant relationship was found between Burnout and gender $(t$-test $(30)=$ $1.910 ; p=.066$ ). Nonetheless, male nurses presented a mean score of 65 , while females had a mean score of 55.33. It was found that the lower the age the higher the Total Burnout $\left(r_{p}=-.449 ; p=0.010\right)$ and the Client-related Burnout $\left(r_{p}=-.559 ; p=0.001\right)$.

Regarding the level of education, the differences observed in Burnout levels were not statistically significant $(t$-test $(30)=0.385$; $p=.703)$. Nurses with a teaching license degree presented a mean score of 60.14 , while nurses with a master's degree had a mean score of 63.67. Likewise, no statistically significant difference was found between different professional categories ( $p>0.05)$, employment in another institution ( $p>0.05$ ), type of schedules ( $p>0.05$ ), weekly workload ( $p>0.05$ ) and the type of employment contract ( $p>0.05)$.

Table 3 - Variables with significant differences in the levels of Burnout, Lisbon, Portugal, 2017

\begin{tabular}{|c|c|c|c|c|}
\hline Variable & Category & $\begin{array}{c}\text { Mean } \\
\text { level of } \\
\text { Burnout }\end{array}$ & $\begin{array}{l}\text { Standard } \\
\text { deviation }\end{array}$ & $\begin{array}{c}\text { Statistical } \\
\text { significance test }\end{array}$ \\
\hline Age & & & & $r_{p}=-0.449 p=0.010$ \\
\hline Desire to change profession & $\begin{array}{l}\text { Yes } \\
\text { No }\end{array}$ & $\begin{array}{l}68.65 \\
51.20\end{array}$ & $\begin{array}{c}14.20 \\
9.31\end{array}$ & $t \operatorname{test}(30 \mathrm{gl})=4.06 ; \mathrm{p}<001$ \\
\hline Desire to change institution & $\begin{array}{l}\text { Yes } \\
\text { No }\end{array}$ & $\begin{array}{l}72.21 \\
51.33\end{array}$ & $\begin{array}{l}11.32 \\
10.20\end{array}$ & $\operatorname{ttest}(30 \mathrm{gl})=5.475 ; \mathrm{p}<001$ \\
\hline Desire to change service & $\begin{array}{l}\text { Yes } \\
\text { No }\end{array}$ & $\begin{array}{l}69.53 \\
52.47\end{array}$ & $\begin{array}{c}14.68 \\
9.78\end{array}$ & $\operatorname{ttest}(30 \mathrm{gl})=3.911 ; \mathrm{p}<001$ \\
\hline
\end{tabular}

Note: $r_{p}=$ Pearson's correlation test; $t$ test $=$ Student's $t$-test; $d f=$ degrees of freedom

Regarding the correlation between Burnout and time of experience, it was verified that: the longer the time in the profession, the lower the Burnout $\left(r_{s}=-.222 ; p=.105\right)$; the longer the time in the institution, the higher the Burnout $\left(r_{s}=.119 ; p=.415\right)$; and the longer the time spent since the last vacation, the lower the Burnout $\left(r_{s}=-.203 ; p=.265\right)$ with statistically non-significant relationships.

It was also verified that nurses who think about changing professions present higher levels of Burnout ( $t$ test $(30 \mathrm{df})=4.06$; $\mathrm{p}<0.001)$, such as those who think about changing institutions (t test $(30 \mathrm{df})=5.475 ; \mathrm{p}<0.001)$ and those who consider changing service $($ test $(30 \mathrm{df})=3.911 ; \mathrm{p}<0.001)$, as shown in Table 3 .

\section{DISCUSSION}

The results obtained demonstrate a high prevalence of Burnout in nurses of an emergency department of a general hospital, with values similar to several studies performed with analogous populations ${ }^{(1,14,16)}$. These data highlight the magnitude of the problem and the attention that should be given by human resource managers. In addition, it justifies the need to keep investigating and monitoring the relationship between work-related variables and personal subscales of professionals. 
No statistically significant relationship was found between Burnout levels and gender, as in other studies ${ }^{(20-21)}$ that also concluded that gender does not significantly interfere with Burnout perception. However, this study found higher levels of Burnout among males than among females. These data contradict other studies $^{(22-23)}$ that found that women are more vulnerable to Burnout due to emotional involvement, role conflicts (double journey, career and domestic life) and also because the nursing is a predominantly female profession.

Younger professionals presented higher levels of Burnout. These results are consistent with some studies ${ }^{(1,13-14,23-25)}$ that raise the possibility that professional immaturity and lack of confidence are related to lack of commitment to work, which in turn contributes to the perception of Burnout. On the other hand, research has revealed interesting and contradictory data. In some studies, age is presented as a factor that does not interfere with the presence and levels of Burnout ${ }^{(26)}$. Other studies mentioned that age alone is not associated with the onset of Burnout, but that this syndrome is related to a set of factors which include age $^{(21)}$. In this study, it was noted that Client-related Burnout is higher among younger professionals, which may be related to the initial difficulty of managing this relationship.

The data showed that people with a higher level of education presented higher levels of Burnout. Other studies ${ }^{(27)}$ have found that professionals with more academic training performed activities with heavier responsibilities and demands. However, we must consider that our sample had a reduced number of specialists and/or nurses with master's degrees.

The number of working hours, which can be associated with high productivity and higher energy expenditure, can lead to instabilities in the individual, in his quality of life, in his relationship with others, and in the quality and safety of the care provided to clients ${ }^{(27)}$. Several studies ${ }^{(13,25,28-29)}$ consider that workload is a relevant factor for Burnout syndrome, because the higher the workload, the higher the level of Burnout. However, other authors ${ }^{(21)}$ found that this factor does not interfere with the existence of Burnout, which is in agreement with the results obtained in this study. It should be noted that the weekly workload common in public services and legally regulated in Portugal is of 40 hours. Some nurses work more hours, as they are also employed in other institutions.

Regarding the time in the profession, several studies demonstrate that professionals with longer work experience have more professional maturity, work more safely and can keep control during times of stress ${ }^{(13,25)}$, which corroborates the results found in this study.

The data point out that vacations serve as a protective factor for Burnout. In the population studied, all had been on vacation in the prior 12 months, and the most significant part had been on vacation in the prior six months. We could wonder if the time elapsed since the last vacation could influence perceived Burnout, but the relationship found was not significant.

An implication for practice is that more attention should be given to factors that may be relevant to the quality of care, including perceived Burnout, which is high among nurses in the context of emergency services. The implications of this syndrome on people's quality of life and on the quality of care is acknowledged.

The data from this study also demonstrated the need to conduct more research on this topic, within a logic of local dimension, focused on human resources management and on optimizing strategies to obtain better health outcomes and improve levels of satisfaction and well-being among professionals. Studies with larger populations, but still focused on the particularity of each service are necessary. In addition, a syndrome with such a high prevalence should be included in nursing education, with the objective of preparing students to identify, prevent, evaluate and minimize it, and to understand how it interferes with the quality of care.

\section{Limitations of the study}

A clear limitation of this study was the small number of participants in the sample. Another limitation in the discussion of these findings is related to the small number of studies with nursing teams of Portuguese emergency services.

\section{Contributions to the area of Nursing, health or public policy}

The intention of this study was to promote reflection on one of the determining factors for professional performance and quality of nursing care, specifically in an emergency department. Work is one of the ways of meetings diverse human needs, such as self-realization, maintenance of interpersonal relationships and survival. The professional subscale is the factor that is most associated with perceived Burnout and special attention should be given to the initial phases of the professional career, since this period is associated with higher levels of Burnout, and with an early intention to change service, institution and even profession.

\section{CONCLUSION}

There is a high prevalence of Burnout among health professionals in general and among nurses in particular. The data in this study demonstrate that Professional Burnout is the most critical subscale of Total Burnout, which requires human resource managers to devote more attention to how workers perceive their working conditions and to whether their stress levels are not in fact the experience of Burnout.

The fact that there are high levels of Burnout among those who want to change service and even institution, in addition to the fact that the relationship with longer work experience is not statistically significant, demonstrates that the current work conditions are what determine higher levels of Burnout.

Age was the most relevant factor related to Burnout. Younger age is associated with higher Burnout score, which is related to the appropriate strategies for integration and professional development in the initial phase of the career. We also found data that, despite their statistical insignificance, seem relevant due to its the clinical importance and association with well-being, such as the time working in the institution and the intention to change profession, institution and service. 


\section{REFERENCES}

1. França SPS, De Martino MMF. Correlations between stress and burnout in mobile prehospital nursing care. Rev Enferm UFPE. 2014;8(12):4221-9. doi: 10.5205/reuol.6825-58796-1-SM.0812201405

2. Maslach C, Jackson S. The measurement of experienced Burnout. J Occup Behav. 1981;2(2):99-113. doi: 10.1002/job.4030020205

3. Maslach C. A multidimensional theory of burnout. In.: Cooper CL, editor. Theories of Organizational Stress. Oxford: Oxford University Press; 1998, p. 68-85.

4. Fonte CMS. Adaptação e validação para português do Questionário de Copenhagen Burnout Inventory (CBI). [Dissertação] [Internet]. Coimbra: Universidade de Coimbra; 2011. [cited 2015 Apr 1]. Available from: https://estudogeral.sib.uc.pt/handle/10316/18118

5. Maslach C. Maslach Burnout Inventory Manual. 3rd ed. Palo Alto: Consulting Psychologist Press, Inc; 1996.

6. Moreno F, Gil GP, Haddad MCL, Vannuchi MTO. Estratégias e intervenções no enfrentamento da síndrome de burnout. Rev Enferm UERJ. [Internet]. 2011 [cited 2016 Jan 12];19(1):140-5. Available from: http://www.facenf.uerj.br/v19n1/v19n1a23.pdf

7. Teixeira M. O Burnout e os enfermeiros [Internet]. 2011 [cited 2017 May 17]. Available from: https://www.monografias.com/pt/trabalhos3/ burnout-enfermeiros/burnout-enfermeiros.shtml

8. Martins CC, Valente GSC. Influence of the stress in the occupational nurses' health who works in hospital emergency. Rev Enferm UFPE. 2010;4(2):86-91. doi: 10.5205/reuol.697-7357-1-LE.0402201012.

9. França SPS, De Martino MMF. Prevalence of psychophysiologial symptoms of stress in the mobile pre-hospital care. Rev Enferm UFPE. 2013;7(1):1-7. doi: 10.5205/reuol.3049-24704-1-LE.0701201301

10. Moreira C, Kilimnik Z, Couto B. Burnout e Fatores de Pressão no Trabalho de Enfermeiros de Unidades de Terapia Intensiva de Belo Horizonte/Minas Gerais. In: IV Encontro Gestão de Pessoas e Relações de Trabalho [Internet]. Brasilia; 2013 [cited 2015 Apr 12]. Available from: http://www.anpad.org.br/admin/pdf/EnGPR76.pdf

11. Batista JV, Barros EO, Morais JMD, Moreira MADM, Costa TF, Brito FM. Burnout syndrome in health workers: integrative review. Rev Enferm UFPE. 2013;7(spe):7118-26. doi: 10.5205/reuol.4767-42136-1-ED.0712esp20132012

12. Grazziano ES, Ferraz Bianchi ER. Impacto del estrés ocupacional y burnout en enfermeros. Enferm Global [Internet]. 2010 [cited 2015 Apr 23];(18):1-20. Available from: http://revistas.um.es/eglobal/article/view/93801/90451.

13. Portela NLC, Pedrosa AO, Cunha JDS, Monte LRS, Gomes RNS, Lago EC. Burnout syndrome in nursing professionals from urgency and emergency services. Rev Pesqui: Cuid Fundam. 2015;7(3):2749-60. doi: 10.9789/2175-5361.2015.v7i3.2749-2760

14. Dantas TRSD, Carreiro BO, Pascoal FFS, Moraes MN, Cordeiro RC, Ferreira Filha MO. Prevalência da síndrome de Burnout entre enfermeiros da rede hospitalar de urgência e emergência. Rev Pesqui: Cuid Fundam. 2014;6(supl):196-205. doi: 10.9789/2175-5361.2014.v6i5.196-205

15. Filgueira CC, Santos VEP, Viera AN. Determinants of work related exhaustion of mobile prehospital nurses. Rev Enferm UFPE. 2012;6(5):11305. doi: 10.5205/reuol.2450-19397-1-LE.0605201222

16. França SPS, Aniceto EVS, De Martino MMF, Silva LL. Sickening process in the nurse's work in mobile pre-hospital care. Rev Enferm UFPE. 2011;6(2):258-66. doi: 10.5205/1981-8963-v6i2a7025p258-266-2012

17. Rosso E, Loures Jr EJ, Aggio CM, Trincaus MR, Possolli GT, Zanoti-Jeronymo DV. Avaliação do nível de estresse entre os profissionais de enfermagem atuantes no SAMU de Guarapuava-PR. Braz J Surg Clin Res [Internet]. 2014 [cited 2015 Apr 26];7(1):13-7. Available from: https://www.mastereditora.com.br/periodico/20140602_103709.pdf

18. Silva JLL, Dias AC, Teixeira LR. Discussão sobre as causas da Síndrome de Burnout e suas implicações à saúde do profissional de enfermagem. Aquichán [Internet]. 2012 [cited 2015 mar. 7];12(2):144-59. Available from: http://www.scielo.org.co/pdf/aqui/v12n2/ v12n2a06.pdf

19. Souza JD, Pessoa Jr JM, Miranda FAN. Stress in an emergency room and the challenges for Brazilian and Portuguese nurses. Rev Enferm Ref. 2017;IV(12):107-16. doi: https://doi.org/10.12707/RIV16064

20. Nogueira CME. Burnout nos enfermeiros do serviço de urgência [Dissertação]. [Internet]. Viana do Castelo: Instituto Politécnico de Viana do Castelo; 2016 [cited 2017 Mar 31]. Available from: http://repositorio.ipvc.pt/handle/20.500.11960/1864

21. França SPS, De Martino MMF, Aniceto EVS, Silva LL. Preditors of Burnout syndrome in nurses in the prehospital emergency services. Acta Paul Enferm. 2012;25(1):68-73. doi: http://dx.doi.org/10.1590/S0103-21002012000100012

22. Galindo RH, Feliciano KVO, Lima RAS, Souza Al. Síndrome de Burnout entre enfermeiros de um hospital geral da cidade do Recife. Rev Esc Enferm USP. 2012;46(2):420-7. doi: http://dx.doi.org/10.1590/S0080-62342012000200021

23. Rolim CSS. Estresse e síndrome de burnout em profissionais de enfermagem. Rev Bras Pesq Saúde. 2013;15(3):103-13. doi: 10.21722/rbps. v15i3.6332

24. Maroco J, Maroco AL, Leite E, Bastos C, Vazao MJ, Campos J. Burnout em profissionais da saúde portugueses: uma análise a nível nacional. Acta Med Port. 2016;29(1):24-30. doi: 10.20344/amp.6460

25. Ritter RS, Fernandes Stumm EM, Kirchner RM, Schmidt Piovesan Rosanelli CL, Ubessi LD. Correlaciones de variables del Inventario 
de Burnout de Maslach en profesionales de urgencia hospitalaria. Enferm Global. 2012;(27):210-23. doi: http://dx.doi.org/10.4321/ S1695-61412012000300012

26. Simões P. Burnout dos enfermeiros nos serviços de saúde em Portugal: um estudo de caso na Saúde 24 Porto [Dissertação na Internet]. Lisboa: Universidade Nova de Lisboa; 2011 [cited 2015 Apr 14]. Available from: https://run.unl.pt/handle/10362/9464

27. Jodas DA, Haddad MCL. Burnout Syndrome among nursing staff from an emergency department of a university hospital. Acta Paul Enferm. 2009;22(2):192-7. doi: http://dx.doi.org/10.1590/S0103-21002009000200012

28. Bezerra FN, Silva TM, Ramos VP. Occupational stress of nurses in emergency care: an integrative review of the literature. Acta Paul Enferm. 2012;25(2):151-6. doi: http://dx.doi.org/10.1590/S0103-21002012000900024

29. Ferreira LI, Duarte TESS, Gouveia Filho PS, Assis EV, Feitosas ANA, Sousa MNA. Estresse no cotidiano de trabalho dos enfermeiros da urgência e emergência. Rev Interdiscip Saúde [Internet]. 2016 [cited 2017 Jan 9];3(1):108-28. Available from: http://interdisciplinaremsaude.com.br/ Volume_9/Trabalho_07.pdf 